\title{
POPULATION ANALYSIS OF EMERGENT TIMBER TREES SPECIES (ETTS) IN IKO ESAI FOREST RESERVE, AKPAMKPA, CROSS RIVER STATE, NIGERIA.
}

I. OJATING

(Received 25 August 2007; Revision Accepted 25 October 2007)

\section{ABSTRACT}

A $5 \times 4$ - factorial study design in a randomized complete block (RCB) with 4 replications was used to analyze the population of emergent timber trees species (ETTs) of Iko Esai Community Forest Reserve in Akamkpa, Cross River State, Nigeria. Six ETTs were encountered in the Forest Reserve. These trees species were Piptadeniastrum africanum (30 trees), Pycnanthus angolense (12 trees), Ricinodendron heudelotii (3 trees), Khaya grandifoliola (4 trees), and Irvingia gabonensis (1 tree). The mean numbers of the ETTs per transect ranged between 0.855 and 1.145 , that of sampling points ranged from 0.9942 to 1.204. There was no significant difference $(P>0.05)$ amongst transects and sampling points in terms of mean numbers of ETTs encountered. The density of all ETTs in Iko Esai Community Forest Reserve was 15.7 trees per hectare. Their average diameter at breast height $(\mathrm{dbh})$ ranged between $76.2 \mathrm{~cm}$ and $84.0 \mathrm{~cm}$, basal area $\left(\mathrm{m}^{2} / \mathrm{ha}\right)$ ranged from 0.8 to 20.0 , relative dominance ranged between $2.0 \%$ and $48.0 \%$, and relative density ranged from 1.8 to $52.7 \%$. In almost all the population parameters mentioned above, Piptadeniastrum africanum ranked first while Irvingia gabonensis took the last position out of six ETTs encountered in the Forest Reserve. Four diameter classes: $0.2 m-0.6 m, 0.6 m-1.0 m, 1.0 m-1.4 m$ and $1.4 m-1.8 m$ were established and the ETTs of Iko Esai Forest Reserve were clustered around diameter classes $0.6 \mathrm{~m}-1.0 \mathrm{~m}$. In view of the high mortality of ETTs brought about by over storey competition, insect and disease attacks, senescence, high rate of exploitation by man etc, it is recommended that the seeds of ETTs should be collected from time to time for the purpose of raising nurseries for pure forest plantation establishment using ETTs seeds.

KEYWORDS: Emergent trees, forest reserve, Iko Esai, Nigeria.

\section{INTRODUCTION}

The survival of the human race on earth is dependent on the continued presence of the forests which are the store houses for all the things needed by man for daily living. Timber is one of those very vital forest products which is needed for the satisfaction of human needs both at home and in factories.

The Nigerian rain forest being an integral part of the world tropical forests has been recognized as one of the richest in timber resources, most stratified (Keay, 1959), and most biologically diverse of all terrestricial ecosystems (Turner, 2001). Kershaw (1973) and Hopkins (1979) have stressed the uniqueness and complexity in stratification of the tropical rain forest including that of Nigeria. According to these authors, three main layers of trees are generally discernible. The upper tree stratum has its wide spreading crowns between (30 $43 \mathrm{~m})$ high, the middle tree stratum occurs about $(23-30)$ high, the lower tree stratum which lies between $(9-23 \mathrm{~m})$ high merges into the shrub stratum below.

In Nigeria the trees which are often felled for use as timber are those of the upper stratum the emergent timber trees (ETTs). This is because the ETTs are the most valuable species suitable for a variety of uses.

It is a well-known fact among foresters and ecologists that ETTs are not always many in number per unit area. Richards (1939, 1940, 1945, and 1952) gave 46.6 species of trees over $0.3 \mathrm{~m}$ girth on the richest plot of 1 hectare in high forest in the Okomu Forest Reserve, Benin with rather lower figures on similar sized plots in Omo Forest Reserve, ljebuOde. The general impression is that the number of species is less in the drier types of high forest (Keay, 1959). Hopkins (1979) has given 20 -25 tree species with minimum diameter of $40 \mathrm{~cm}$ on 1 ha sample plot of a typical rain forest of West Africa.

Because of the fewness of the ETTs per unit area of the rain forest and because of the heavy exploitation of these species by man, Okigbo (1964) has alerted the Nigerian public about the existence of some lesser-known tree species, which he considers, are of comparable quality with the ETTs. But these lesser-known species are according to the author, seldom felled or extracted except by special request. Therefore there is the practice of the timber exploiters to continue to fall back to the very few ETTs.

Consequent upon this, the ETTs of the Nigerian rain forest are now threatened with extinction. This situation becomes even more worrisome when it is known that ETTs die frequently as a results of disease and insect attacks, inclement weather, overstorey and under story competition, senescence, over exploitation by man etc. The death of ETTs as a result of lightening, wind, insects and diseases attacks, and old age has been reported by Spurr and Barnes (1973).

To avoid extinction of ETTs, there is the need for their sustainable management to ensure their continued existence and supply for use in the household and industry.

To this end, Okojie et al. (1988) aver that to ensure sustainable management of a forest and its resources including timber, quantitative information which include the abundance/density of each species, stem diameter distribution, basal area, population per unit area of each species etc are indispensable.

The main objective of this pioneer study was therefore, to carry out a qualitative and quantitative inventories of the ETTs of Iko Esai Community Forest Reserve so as to supply the necessary information on the vital parameters of the population of these trees species.

The specific objectives were: (1) Find out the mean number of ETTs per sampling point along each transect in the Forest Reserve, (2) To determine some of the useful population parameters of ETTs such as diameter at breast height (dbh) of the trees, their basal area, density per hectare, relative dominance, relative density and the number of each species. (3) Determine diameter distribution of the ETTs and group them into diameter classes.

This study is significant and very important in the sense that it was planned to generate qualitative and quantitative, biometrical information of ETTs of Iko Essai Community Forest Reserve. Such information is very vital and 
needed as a base-line data which could be used to effectively plan for the sustainable management of ETTs of the Forest Reserve.

\section{MATERIALS AND METHOD}

\section{Time and Location of Study}

This pioneer study, to carry out a qualitative and quantitative analyses of all emergent trees species (ETTs) of Iko Esai Community Forest Reserve, was undertaken in April, 2007.

The protected area of 400 hectare Iko Esai Community Forest Reserve lying between latitudes $5^{\circ} 40^{\prime}$ and $5^{\circ} 41^{\prime} \mathrm{N}$ and longitudes $8^{\circ} 16^{\prime}$ and $8^{\circ} 18^{\prime} \mathrm{E}$, is located in Akamkpa Local Government Area of Cross River State, Nigeria.

The 400 - ha core Area of the Forest Reserve is protected by "CERCOPAN" - a non-profit, non-governmental organization dedicated to conserving Nigeria's primates through rainforest conservation, community education, primate rehabilitation and research. The area supports an incredible variety of plant and animal life. The 400-ha core Area is protected from logging, farming, hunting and gathering of forest products. This area is bounded on the east by the Roko River.

\section{METHODOLOGY}

Six transects $\left(T_{1}-T_{6}\right)$, each measuring $1 \mathrm{~m}$ wide and $480 \mathrm{~m}$ long were laid out in an east-west direction. Out of the Six transects, $T_{1}, T_{2}, T_{3}, T_{4}$ and $T_{5}$ were selected and used as base lines for the study since these transects, i.e $T_{1}-T_{5}$, lie right in the center of the Forest Community. Equal distances of $40 \mathrm{~m}$ apart were measured along each of these transects thus locating the points, $1-28$. Out of these points, twenty random points, 1,3, 5, 7, 9, 11, 12, 14, 16, 17, 18, 19, 20, 21, 22, 23, $24,26,27$ and 28 were selected from a table of random numbers (Kershaw, 1973) and were used as sample study/inventory points. From each of the random sample/study/inventory points, an imaginary line was drawn perpendicular to the base line (Hopkins, 1979).

At each point of intersection of the imaginary perpendicular line and the base line/transect, a cluster of four subplots (pseudo-replications) or quadrants (Hopkins, 1979); Wong et al (2001), each measuring $20 \mathrm{~cm}$ by $20 \mathrm{~cm}$ were measured. Within each of he four quadrants or subplots so produced, the nearest ETTs to the random point were selected. For each of these trees the following items were recorded: distance from the random point, diameter at breast height and name of the species. This procedure was repeated for all the random point: $1,3,5,7,9,11,12,14,16,17,18$, $20,21,22,23,24,26,27$ and 28.

The ETTs were inventoried in a total of 80 subplots, thus $1 \%$ of the forest community was assessed. According to Wong et al. (2001), more than 30 such subplots are considered sufficient and adequate. Hopkins, (1979) has recommended $1 \%, 5 \%$ or $10 \%$ enumeration of a forest as adequate when sample subplots are used.

From the quantitative data so generated, the following data were calculated according to Hopkins, (1979).

(1) Mean distance $d=$ sum of all distance measured/number of distance measured.

(2) Density $=1 / \mathrm{d} 2$, so that the density per hectare $=$ $=10,000$, when $\mathrm{d}$ is in $\mathrm{m}$

$$
\mathrm{d} 2
$$

(3) Relative density $=$ number of individuals of that species $\times 100$ number of individual of all species

(4) relative dominance $=\underline{\text { total basal area of that species }} \times 100$ total basal area of all species

(5) Basal area of each species was calculated using the formula:

$$
\begin{aligned}
B \cdot A=T^{T T D^{2}}, \text { where } & B . A \\
& = \\
& \text { Basal Area, } \\
D & =d b h \\
& \Pi=3.142 .
\end{aligned}
$$

Other statistical data of the ETTs generated per transect and per sampling point, using a 2 - factor factorial design were analyzed following the methods of Wahua (1999).

\section{RESULTS AND DISCUSSION}

Six ETTs were encountered in Iko Esai Community Forest Reserve. These tress species are Piptadeniastrum africanum, Pycnanthus angolense, Triplochiton scleroxylon, Ricinodendron heudelotii, Khaya grandifoliola, and Irvingia gabonensis.

The following description given in this study for six ETTs of Iko Esai Community Forest Reverse do not differ from that of keay (1989).

Piptadeniastrum africanum (Hook. F.)

Brenan (Legumiosae: mimosoideae). This tree is a large forest tree with conspicuous buttress and fine fern-like foliage. Tree up to $45 \mathrm{~m}$ high and $3.4 \mathrm{~m}$ in girth, with widely spreading rather flat crown. Bole straight and clear of branches reaching up to $3 \mathrm{~m}$ high or more often branching at the base.

Habitat: forest. Flowers (June - September) yellowish white. Fruits (Oct. - March) $15-35 \mathrm{~cm}$ long by $18-32 \mathrm{~mm}$ broad.

Pycnanthus angolense (Welw.) Ward. (Myristicaceae) commonly known as 'cardboard' in the Cameroun where it is split into rough planks for house building (Keay, 1989). This is a forest tree with slender branches. Habitat: lowland rain forest. Tree up to about $30 \mathrm{~m}$ high and $2.5 \mathrm{~m}$ in girth, occasionally more; evergreen. Bole straight, cylindrical without buttress. The leaves are so often eaten by insects that this is a characteristic feature. Flowers (Dec - March. June) densely clustered at the ends of irregularly branched panicles.

Triplochiton scieroxylon K. Schum Sterculiaceae.

Habitat: lowland rain forest and forest outliers. Especially characteristic and frequent in the drier and more disturbed forest. Tree up to $55 \mathrm{~m}$ high and $7 \mathrm{~m}$ girths with large buttress and cylindrical bole, deciduous. Flowers (Dec. - Feb.) in short panicles, petals white. Fruits (Feb. - March) composed of 1 5 winged carpels about $6 \mathrm{~cm}$ long.

Ricinodendron heudelotii (Baill.) Heckel (Euphorbiaceae). Subsp. africanum (Muell. Arg.) Leonard. Large forest tree. Habitat: drier forest regions, and especially secondary forest. Tree up to $50 \mathrm{~m}$ high and $2.5 \mathrm{~m}$ in girth. Decidsuous. Bole usually straight, sometimes with short buttresses. Flowers (March - May) usually in terminal panicles. Fruits (May - Oct.) at first stellate hairy, $2.5 \mathrm{~cm}$ or more across containing 2 or occasionally 3 seeds.

Khaya grandifoliola C. Dc. (Meliaceae). Habitat: drier part of the forest zones. Tree up to $40 \mathrm{~m}$ high and $5 \mathrm{~m}$ girth, conspicuous when bearing the bright red young foliage. Leaves with $3-4$ pairs of leaflets, $12-20 \mathrm{~cm}$ long by $5-$ $10 \mathrm{~cm}$ broad, rather thin and papery compared with the other species. Flowers (Dec. - Feb.) cream in panicles. Fruits (Jan. - June) usually with 5 (rarely 4 ) massive values, each about $9 \mathrm{~cm}$ long and $8 \mathrm{~mm}$ thick.

Irvingia gabonensis (O'Rorke) Baill (Irvingiaceae). The wild mango or Dika nut, with mango - like fruits. The tree may be readily recognized by its dense dark green evergreen foliage and characteristic stipules which are similar to those of Klainedoxa but smaller. Habitat: forest; var excelsa prefers wetter situations and sometimes gregarious. Tree to $35 \mathrm{~m}$ high and $2 \mathrm{~m}$ in girth; occasionally more. Flowers (Nov. - March, June) yellowish to greenish white. Fruits (April - July; Sept.) yellowish, $5-7.5 \mathrm{~cm}$ with a yellowish fibrous surrounding a large stone.

The results of the mean numbers of ETTs prevalent in IKO Esai Community Forest Reverse is given in table 1. These mean numbers of the ETTs are presented for every transect and every sampling/inventory point. The mean numbers per transect ranged between 0.855 and 1.145 ; that of sampling points ranged between 0.942 and 1.204 . The overall mean number of the ETTs for all the transects and sampling points was 1.026. 
Table 1: Mean number of ETTs per transect per sampling point

\begin{tabular}{|l|l|l|l|l|l|}
\hline \multirow{2}{*}{ Transect (T) } & \multicolumn{5}{|c|}{ Sampling points } \\
\cline { 2 - 6 } & 1 & 2 & 3 & 4 & Mean for $\mathrm{T}$ \\
\hline $\mathrm{T}_{1}$ & 1.35 & 1.05 & 0.70 & 0.95 & 1.0125 \\
\hline $\mathrm{T}_{2}$ & 1.15 & 1.05 & 0.95 & 0.95 & 1.025 \\
\hline $\mathrm{T}_{3}$ & 1.17 & 1.17 & 1.17 & 1.07 & 1.145 \\
\hline $\mathrm{T}_{4}$ & 1.40 & 0.95 & 0.82 & 1.20 & 1.0925 \\
\hline $\mathrm{T}_{5}$ & 0.95 & 0.70 & 1.07 & 0.70 & 0.855 \\
\hline Mean for sampling points & 1.204 & 0.984 & 0.942 & 0.974 & 1.026 \\
& & & & & \\
\hline
\end{tabular}

The average diameter at breat height ( $\mathrm{dbh}$ ) of every ETTs, their basal areas, relative dominance and relative density are summarized in table 2.

Table 2: ETTs of Iko Esai Forest Reserve their diameter at breast height (dbh), basal area, relative dominance, relative density and number of species

\begin{tabular}{|l|l|l|l|l|l|l|}
\hline \multirow{2}{*}{ S/N } & & \multicolumn{5}{|c|}{ Parameters } \\
\cline { 3 - 7 } & & $\begin{array}{l}\text { Dbh* } \\
\text { Average } \\
(\mathrm{cm})\end{array}$ & $\begin{array}{l}\text { Basal Area } \\
\left(\mathrm{m}^{2} / \mathrm{ha}\right)\end{array}$ & $\begin{array}{l}\text { Relative } \\
\text { dominance }(\%)\end{array}$ & $\begin{array}{l}\text { Relative } \\
\text { density }(\%)\end{array}$ & $\begin{array}{l}\text { Number of } \\
\text { tree } \\
\text { species }\end{array}$ \\
\hline 1 & $\begin{array}{l}\text { Pitadeniastrum } \\
\text { africanum }\end{array}$ & 87.4 & 20.0 & 48.0 & 52.7 & 30 \\
\hline 2 & Pycnanthus angolense & 89.3 & 10.7 & 25.7 & 21.8 & 12 \\
\hline 3 & Triplochiton scleroxyon & 76.2 & 3.9 & 9.3 & 9.1 & 5 \\
\hline 4 & $\begin{array}{l}\text { Ricinodendron } \\
\text { heudelotii }\end{array}$ & 79.7 & 3.1 & 7.5 & 7.3 & 3 \\
\hline 5 & Khaya grandifoliola & 77.5 & 3.1 & 7.4 & 7.3 & 4 \\
\hline 6 & Irvingia gabonensis & 84.0 & 0.8 & 2.0 & 1.8 & 1 \\
\hline
\end{tabular}

From this table, it is seen that while the range of the average $\mathrm{dbh}$ of the ETTs is between $76.2 \mathrm{~cm}$ and $89.3 \mathrm{~cm}$, Pycnanthus angolense had the highest average $\mathrm{dbh}$ of $89.3 \mathrm{~cm}$, this was followed by Piptadeniastrum africanum $(87.4 \mathrm{~cm})$, Irvingia gabonensis was third with $84.0 \mathrm{~cm}$, Ricinodendron hendelotii was $4^{\text {th }}(79.7 \mathrm{~cm})$, Khaya grandifoliola came fifth with $77.5 \mathrm{~cm}$ and Triplochiton scleroxylon had the least average $\mathrm{dbh}$ of $76.2 \mathrm{~cm}$.

The basal areas of the ETTs ranged between 0.8 and $20.0 \mathrm{~m}^{2} / \mathrm{ha}$. Piptadeniastrum africanum had the highest basal area of _ $20.0 \mathrm{~cm}^{2} / \mathrm{ha}$, and Irvingia gabonensis the least basal area of $0.8 \mathrm{~m}^{2}$. The relative dominance of Iko Esai Forest Reserve ETTs ranged between 2.0 percent and 48.0 percent, Piptadeniastrum africanum was the most dominant ETTs, having 48.0 per cent dominance. The least dominant species was Irvingia gabonensis with 2.0 percent dominance. Pycnanthus angolense with 25.7 percent was second to Piptadeniastrum africanum, Triplochiton Scleroxylon took the third position with 9.3 per cent dominance, while Ricinodendron heudelotii and Khaya grandifoliola with 7.5 and 7.4 per cent dominance occupied the $5^{\text {th }}$ and $6^{\text {th }}$ positions respectively.

Relative density of ETTs in Iko Esai Community Forest Reserve ranged from 1.8 per cent for Irvingia gabonense to 52.7 per cent for Piptadeniastrum africanum. Pycnanthus angolense had 21.8 per cent for Piptadeniastrum africanum Pycnanthus angolense had 21.8 per cent relative density and occupied the second position while Triplochiton scleroxylon, Ricinodendron hendelotii, Khaya grandifoliola occupied the $3^{\text {rd }}, 4^{\text {th }}$, and $5^{\text {th }}$ positions with relative density scores of $9.1,7.3,7.3$ per cent respectively.

The density of all ETTs in Iko Essai Community Forest Reserve was 15.7 trees per hectare. This density of 15.7 emergent trees per hectare obtained in this study for lko Esai Forest Reserve, with an average minimum dbh range of
$76.2 \mathrm{~cm}-89.3 \mathrm{~cm}$ for all the ETTs does not differ markedly from the Hopkins (1979) range of $20-25$ trees species per hectare, with a minimum average diameter at breast height of $40 \mathrm{~cm}$. The slight difference between the data obtained in this study and that of Hopkins lies in the fact that Hopkins data were collected from sample plots of different sized trees growing in a typical unspecified tropical lowland rain forest. Of these species, some will be relatively uncommon and occur as scattered individuals throughout the forest whilst others will be more common (Hopkins, 1979). This author has further revealed that one species may account for up to one-third of all the individuals of the middle or lower strata, or for up to one-fifth of all the individuals of the upper tree stratum; it is however, rare for one species of tree to predominate in this peculiar situation of different-sized trees of different strata.

From the foregoing explanation by Hopkins (1979), it is quite clear that while Hopkins dealt with approximate number of trees of all size classes in a typical lowland rain forest of West Africa, my study concerned itself with only emergent trees species of the uppermost stratum in a typical secondary dry rain Forest Reserve of Iko Esai Community in Akamkpa L. G. A., Cross River State, Nigeria.

Another data published by Richards (1939) and then Keay (1959) gave 46.7 trees of all diameter classes from all forest strata on the richest plot in high forest (primary rain forest) in Okomu Forest Reserve, Benin with rather lower figures on similar sized plots in Omo Forest Reserve, ljebu Ode, Western Nigeria.

Keay (1979), has rightly observed, that the general impression is that the number of tree species is less in the drier types of high forest and increases towards the Southeastern part of the forest zone within the region.

The diameter classes of the ETTs of Iko Esai Community Forest Reserve is presented in table 3 . 
Table 3: Stem diameter distribution of ETTs in Iko Esai Forest Reserve, Akpamkpa LGA, Cross River State, Nigeria.

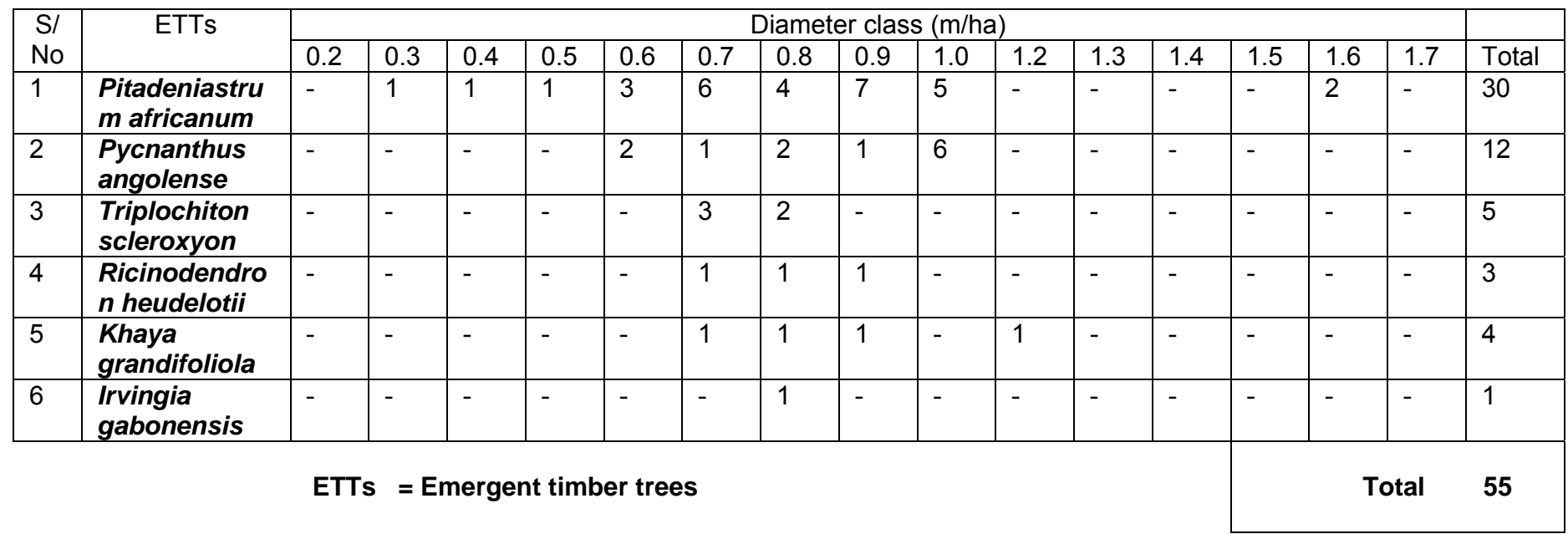

From this table, four obvious diameter classes are recognized. These are:

$0.2 \mathrm{~m}-0.6 \mathrm{~m}-$ class I

$0.6 \mathrm{~m}-1.0 \mathrm{~m}-$ class II

$0.1 \mathrm{~m}-1.4 \mathrm{~m}-$ class III

$1.4 \mathrm{~m}-1.8 \mathrm{~m}-$ class IV

The 55 ETTs of Iko Esai Community Forest Reserve were grouped into these four classes as follows: class $1-9$ speces, class II -44 species, class III -2 species, and class IV - O species.

From table 3, it is seen that the ETTs of Iko Esai Forest Reserve clustered around diameter classes $0.6 \mathrm{~m}-$ $1.0 \mathrm{~m}$, i.e diameter class II.

The result of the distribution of ETTs of Iko Esai Forest Reserve into diameter classes could not be corroborated with any other result since no such study has been undertaken previously by any one in this part of the country. If any such study exists, it is at least not at my disposal.

\section{CONCLUSION AND RECOMMENDATIONS}

Since this study is the first so far carried out for lko Esai Community Forest Reserve, it should be taken as a pioneer work and the data/result generated treated as a baseline information on ETTs of the Forest Reserve.

The six trees species identified in this study as ETTs of Iko Esai Forest Reserve had also been identified and recognized by other workers and leading authors as trees species of the uppermost storey or stratum of the tropical rain forest of Nigeria (Keay, 1959; Okigbo, 1964; Hopkins, 1979; Okafor and Fernamdes, 1987).

ETTs face a variety of hazards, such as overstorey and understorey competitions, over - harvesting by man, diseases, insects and fungal attacks, inclement weather and senescence. As a result of these numerous hazards, ETTs are endangered trees species facing possible extinction.

In order to prevent the eminent danger of extinctions, there is therefore the need to constantly carry out inventories of them so as to monitor their population status in time and space. The results of such studies will enable foresters and policy makers make adequate plans for the sustainable management of ETTs.

\section{RECOMMENDATIONS}

1. Frequent inventories of ETTs should be carried out

2. Seeds of ETTs should be collected from time to time for storage and for nurseries establishment

3. Pure forest plantations made up of ETTs should be established to ensure their availability all the time

\section{REFERENCES}

Hopkins, B., 1979. Forest and Savanna Second Edition, Heinemann, Ibadan and London, 154pp.

Keay, R. W. J., 1959. An Outline of Nigerian Vegetation. Third Edition. Federal Department of Forest Research. $46 \mathrm{pp}$.

Keay, R. W. J., 1989. Trees of Nigeria. Clarendon Press, Oxford. 476pp.

Kershaw, K. A., 1973. Quantitative and Dynamic Plant Ecology. Second Edition. The English Language Book Society and Edward Arnold (Publishers) Ltd.; London. 306pp.

Okafor, J. C. and E. C. M. Fernandes; 1987. Compound Farms of Southeastern Nigeria. A Predominant Agroforestry hamegarden System with Crops and Small Livestock. Agroforestry Systems: 153 - 168.

Okigbo, L., 1964. Some Nigerian Woods Second Edition. Federal Forest Research, Ibadan, Nigeria. 60pp.

Okojie, J. A., Borders, B. E. and Bailey, R. L., 1988. Forest Composition and Structure During a 27 Year Period of Observation in an Untreated Secondary Lowland Rainforest in Southwestern Nigeria. Forest Ecology and Management 24: $247-262$.

Richards, P. W., 1939. Ecological Studies on the Rain Forest of Southern Nigeria, The Structure and Floristic Composition of Primary Forest; Ecol. J. 22.

Richards, P. W., 1940. The Recording of Structure, Life-form and Flora of Tropical Forest Communities as a Basis for their Classification; J. Ecol. 23.

Richards, P. W., 1945. The Floristic Composition of Primary Tropical Rain Forest; Bio. Rev. 20.

Richards, P. W., 1952. The Tropical Rain Forest; Cambridge 
Spurr, S. H. and Barnes, B. V., 1973. Forest Ecology. Second Edition. The Ronald Press Company. New York. $571 \mathrm{pp}$.

Turner, I. M., 2001. The Ecology of Trees in the Tropical Rain Forest. Cambridge University Press, Cambridge, UK. $298 \mathrm{pp}$
Wahua, T. A. T., 1999. Applied Statistics for Scientific Studies. Afrika-link Books, Owerri, Ibadan, Abuja.

Wong, L. G. J., Thornber, K and Nell, B., 2001. Resource Assessment of Non-wood Forest Products. Experience and Biometric Principles. F. A. O., Rome. 